\title{
Educational Improvement Towards Effective Madrasah
}

\author{
Nurkolis \\ Program Studi Manajemen Pendidikan \\ Universitas PGRI Semarang \\ J1. Sidodadi Timur No. 24 Semarang \\ nurkolis@upgris.ac.id
}

\begin{abstract}
The objectives of this article to know: how was the quality of madrasah, how was the efficiency of madrasah, how was the professionalism of madrasah teacher, and how was the quality of madrasah graduates in Central Java Province. The approach of study was descriptive quantitative utilizing document from the Ministry of Religious Affairs and the Ministry of Education and Culture. The research process following the procedure of Miles and Huberman. The study was conducted in 2017 with secondary data of institutional and student achievement in 2014-2016. The results showed that: majority of madrasah quality were in good categories; the majority of madrasah provision has been efficient but lot of learning group were inefficient seen from the number of students and teachers' teaching load; the majority of madrasah teachers were professional but many teachers were not professional seen from academic qualifications and ownership of certificates; and the quality of madrasah was still low when compared with the same level of education. Based on these results it is advisable to carry out institutional reform of madrasah with better institutional management, better organize of teachers, and create better policy towards effective madrasah.
\end{abstract}

Keyword-madrasah reform; madrasah quality; education efficiency; the professionalism of teachers; and the quality of graduates.

\section{INTRODUCTION}

The history of madrasah education in the world have started since the $5^{\text {th }}$ century with the establishment of the first madrasah in Nishapur, Iran. Madrasah education increasingly prominent in the $10^{\text {th }}$ century in Baghdad. In the $19^{\text {th }}$ century madrasah education began in Indonesia with the establishment of Madrasah Adabiyah in 1910 in Padang Panjang, West Sumatra. At the beginning, madrasah education focuses on teaching religion and not paying attention to the social subjects such as social, political, economic, and cultural. As a result, madrasah education received less attention from government and society at large. Then madrasah graduates experienced problems especially in employment [1].

Madrasah is one of the models of Islamic education in Indonesia. Two models of Islamic education is Pesantren and Islamic schools [2]. Pesantren generally held traditionally and learners stay in school and eventually became known as the boarding school. Islamic school is educational institutions that teach either general knowledge and religious, under the coordination of the District of Education Office and the Ministry of Education and Culture (MOEC).

Madrasah is a form of education under the supervision of the Ministry of Religious Affair (MORA) and following the general regulations issued by MOEC. Because it is under the two ministries, some parties considered that madrasas get different treatment compare from the school. But in reality government treated equally between Madrasah Ibtidaiyah (MI) with Elementary School (SD), Madrasah Tsanawiyah (MTs) with a Junior High School (SMP), and Madrasah Aliyah (MA) with High School (SMA).

One of the equality treatment between madrasah and school was in terms of education funding. The Indonesian government has to act fairly to treat schools and madrasah wether private or state. Similarities between madrasah and school have been secured since the enactment of Law No. 4 years 50 which stated that studying in religious schools which have gained recognition from MORA deemed to have fulfilled the obligation to learn [3]. This means that education madrasah and school have the same status. In 1950 the madrasah received government aid amounting to Rp. 60 each student in a year, also to schools [4].

Equality treatment between madrasah and shool also evident with the enactment of Law No. 2 Year 1989 on National Education System [5]. Mentioned that education was carried out through two channels, namely school channel and outside the school. Education track consists of general education, vocational education, special education, service education, religious education, academic education and professional education. Special religious education requires the mastery of the religious teachings are concerned.

The alignment between madrasah and schools even stronger with the enactment of Law No. 20 of 2003 on National Education System. There is no dichotomy between schools and madrasah either primary or secondary. It is mention that basic education in form of SD and MI or SMP and MTs or other equivalent form. Similarly in article 18 mentioned that secondary education in form of SMA, MA, SMK, and MAK or other equivalent form [6].

Since 2005 to 2017 , the government has consistently acted fairly by providing school operational assistance (BOS) for 
students of SD and MI as much as Rp. 800,000, for students of SMP and MTs as much as Rp. 1,000,000, and for students of SMA, MA, and MAK as much as Rp. 1,400,000 each student in a year.

But in reality people are still underestimated and defer the madrasah education. This is because the public perception of madrasah still mistakenly regard as study Al-Quran only. Still there is a presumption tilted towards madrasah like a rundown building, poor teacher quality and unprofessional, the teacher does not have a formal certificate, and unsold madrasah graduates to work [7].

Under these conditions, the authors felt it was important to examines at the madrasah education management in a comprehensive manner. So far it has not been found studies of comprehensive management of madrasah education on national, provincial, or district/city level. Some study more on madrasah curriculum content, process of teaching and learning, or student achievement of such as conducted by Zuhdi [2]. Some study on madrasah management partially conducted by Makruf [8], Yasin [9], Natsir [10], Hurmaini [11], Sanaky [12], and Haningsih [13].

So it is important to know comprehensively madrasah education in Central Java Province which consists of: the quality of madrasah institutions, the efficiency of madrasah, the madrasah teacher professionalism, and the quality of madrasah graduates. The findings will be the basis for recommendations in order toward effective madrasah in Central Java Province.

\section{METHOD}

This article is based on research conducted with qualitative descriptive approach. The analysis model following Miles and Huberman and conducted in February 2017. The steps of research was to collecting data through documentation, write down the findings in the scrapbook to acquire new findings, categorize findings, and conclusions. Data obtained from secondary data of Education Magemagement Information System of MORA on second half of 2016 year and report of national exam in 2014/2015 to 2015/2016 from MOEC. All MI institutions as many as 4,025 and all MTs as many as 1,666 institutions became the sample, it was called a survey research. Number of active educators in MI was 43.008 people and active educators in MTs as many as 34.081 people. The definition of active educators was educators are not currently continue studiying in universisy, did not on a study permit, did not on leave, or did not served at other institutions.

\section{A. The Institutional Quality of Madrasah \\ III. RESULT AND DISCUSSION}

Institutional quality can be seen from the accreditation status of madrasah, the institutional providers, the number of students repeating on the same grade, the number of students drop out, and graduation rates of students.

Madrasah quality can be seen from the number of accreditation with satisfying result. The result of accreditaion with $\mathrm{A}$ or B, and a good education provider are organized by institutions of organizations such as foundations or religious organizations. Although accreditation of madrasah still emphasize on aspects of administration, but so far it is quite an effective tool to promote the quality of the school.

By 2016 the number of MI in Central Java Province as much as 4,026 institutions which consist of public MI 114 (2\%) and private MI 3. 9123 (98\%) institutions that spread out in 35 districts/cities. This condition was slightly different from the overall national private madrasah in the amount of $94 \%$ and publik of $6 \%$. In general, private madrasah still dominating MI in the country.

Based on the accreditation result, as many as $841(21 \%)$ MI accredited A, as many as 2,533 accredited B (63\%), an accredited C as many as 294 (9\%), and has not accredited 294 (7\%) of the institution. This means that the majority of MI has had a satisfactory accreditation A and B of $84 \%$ or have good quality and only $16 \%$ that the quality is not satisfactory. If compare with national condition, the accredited of MI in Central Java was better. Nationally madrasah that have not accredited as many as $15 \%$ and that has accredited only $50 \%$ getting A [14].

By 2016 the number of MTs in Central Java Province as many as 1,666 institutions [9] consists of public MTs 121 $(7 \%)$ and private MTs $1,545(80 \%)$. Based on the accreditation status of $382(23 \%)$ accredited A, a total of $954(57 \%)$ accredited B, and $196(12 \%)$ accredited C, and as many as 134 $(8 \%)$ have not been accredited. That was equal to $80 \%$ of MTs already meet accreditation satisfactory or good quality and only $20 \%$ was not satisfactory or the quality was not good. Means that the institutional conditions of MTs in Central Java Province was better than the condition of madrasah nationwide.

Collectively madrasah education providers were generally better than the individual. The provision of educational resources will be more complete and secure. Collective education providers usually by a foundation or religious organization.

Majority of educational service of MI provided by foundation of $88.45 \% \quad(3,561$ institutions $)$, by religious organizations of $8.79 \%$ (354 institutions), by individuals of $0.30 \%$ (12 institutions), and $2.46 \%$ (99 institutions) outside those three organizers. Scrutiny of religious organizations providers as much as $52 \%(2,105 \mathrm{MI})$ under the auspices of the NU, 16\% (645 MI) under the auspices of Muhammadiyah, $2 \%(80 \mathrm{MI})$ under other religious organizations, and $30 \%$ (1.196) under the organization in addition to religious or personal. This shows that the community's commitment to madrasah education in Central Java Province very well.

The majority of MI under the auspices of the boarding school (pesantren) in the amount of $95.9 \%$ (3,863 MI), only $3.78 \%$ (152 MI) were not under the auspices of the boarding school (pesantren), and the remaining $0.27 \%$ (11 MI) have not been identified. Judging from the operational time of $98,98 \%$ 
(3,985 MI) held in the morning, $0.05 \%$ (2 MI) held in the afternoon, and $0.97 \%$ (39 MI) combined morning and afternoon.

The majority of MTs organized by the foundation as many as 1,483 (89\%), $78(5 \%)$ by religious organizations, and 93 $(6 \%)$ by individuals while as many as $12(<1 \%)$ unidentified organizers which may be run by private individuals. As well as the implementation of MI, MTs organizers also dominated by a group of people who care about the Islamic education and formed an organization whether it be a foundation or religious organization. It also showed that community participation in MTs education was very good.

The high number of private MI and MTs and the large percentage of private MI and MTs organized by the foundation or religious institutions showed high community participation in Islamic education. Private and community is an important part of education, including educational funding as stipulated in Law No. 20 of 2003 that education is a shared responsibility among central government and local government, parents, and community.

The number of students repeating is one indicator of the quality of educational institutions. The more students who repeat indicates less optimized classroom learning system. The number of students who repeated in MI nationaly reached 6,348 students and MTs 53,057 students. In Central Java Province, students who repeat worse than the average percentage of national. For MI student who repeat in Central Java was 1.64>1.40 for MI nationally. For MTs students who repeat also hihger than the national conditions 2.92>1.76 [15].

Quality of education institutions can also be seen from the drop out rate of students. The higher level of drop out rate of students indicated that less maximum of educational services. The number of MI students who drop out nationwide reached 5,803 people and MTs students who drop out reaches 14,564 people. The drop out rate in Central Java was better than the national average. Drop out rate for MI in Central Java MI 0.10 $<0.14$ for national, and for MTs $0.33<0.41$ [15].

Number of graduation also shows the quality of the institution. The higher the graduation rate, the better the quality of educational institutions. Nationally, the number of students who do not pass MI level in the year 2014/2015 as many as 401 people, and MTs students who do not pass as many as 1,382 people [15].

Until now, the management of madrasah education management is done centrally, whereas the Indonesian government has made several stages of the reform, including reform of the education sector. Education reform in Indonesia has started since Law 22 of 1999 on Regional Government which has been amended several times and the last out of Law No. 23,2014. Excluding the madrasah, education has been decentralized, because the madrasah education under the authority of the MORA are still managed centrally. Therefore, the more advanced the decentralization of education applied in schools than in madrasah. Based on the research results one of the principles of madrasas-based management in forms of community participation was not visible at the madrasah. Participation of parents and communities in the management of madrasah was low and was centered on the leadership of headmaster [16].

It is important to be an alternative to institutional management policies in order to reform the madrasah management. Madrasah should be decenralized from the MORA at central level to provincial or district/city level. In this way, the purpose to be effective madrasah would be more easily achieved. Effective madrasah in this context have similar meaning with effective schools, because schools and madrassas have the same meaning in serving education.

The importance of madrasah education reform becomes urgent to be done in order to establish effective madrasah. According Scheerens sense of school effectiveness (madrasah effectiveness) most commonly refers to the level of achievement of the goals of the school/madrasah [17]. The purpose of the study of the effectiveness of school/madrasah to understand the functions of school/madrasah and influence to the students, even his influence to improve the functions of the school/madrasah [18]. This means that a reformed madrasah would be better so that goals of madrasah can be achieved optimally.

One of the goals of madrasah in Indonesia is that the graduates have characteristics of Islam Nusantara. The label "Islam with a smiling face" depicts Islam in Indonesia that is inclusive, progressive, and modern. Islamic face with a strong tradition of Islam Nusantara also form an inclusive, progressive, and modern schools. School to be inclusive, to be pluralist, and to be progressive emphasizing on strong rationality and autonomy as well as modern with preparing students to meet the challenges of the globalized world and knowledge-based economy [19].

Indonesian Islamic schools have taken great roles to narrow the gap between general education and religious education. For example, in higher education, has built a bridge between Islamic higher education and non-Islamic higher education in the process of creating one of the world's best Islamic university system. Reconstruction of Islamic education is also supported by the role of Islam in shaping the direction of political evolution in Indonesia [20].

To be effective madrasah, it seems necessary to reform the madrasah education. Education reform can be carried out in various sectors namely education budget, educational goals, educational resources such as human and infrastructure, as well as the educational process [21].

\section{B. The Efficiency of Madrasah Operation}

The efficiency of madrasah can be seen from the number of students per school or the number of pupils per group learning, teachers' teaching load, the number of student repeated, the number of students drop out, and the number of students who did not pass final exam. The smaller number of 
students per school or per-group learning, the more inefficient. The less a teacher teaching loads more inefficient. The greater the number of students who repeat, the higher drop out rate, and the greater number of students who do not pass exam the more inefficient.

If number of students is too little become inefficient because of educational resources in the form of teachers or education personnel, funds, facilities, infrastructure and other resources only enjoyed by few students. When referring to the national standard of education, the number of MI students in each class maximum of 28 students. If the number of students over the standard will result in a lower effectiveness of the learning process, but if far lower from maximum standard becomes inefficient.

The fewer the number of teaching hours for each teacher, more inefficient. This is because a teacher has determined his salary fixed. The government determined that the number of teaching hours of a teacher between 24-40 hours per week. If a teacher teaches less than 24 hours per week, then she/he will still get a one month salary. Shen teachers teach between 2440 hours and hold teacher certification then they will get professional allowance as much as for one month salary [22].

If seen from the number of students in institution, most of MI serve between 101-300 students as much as $58.17 \%(2,342$ MI), the number of students in each MI up to 100 students as much as $35.47 \%(1,428 \mathrm{MI})$, and the number of students more than 300 students as much as $6.36 \%(256 \mathrm{MI})$. Most of MI have learning group of 6 as many as $68.85 \%(2,772 \mathrm{MI})$, has a learning group of $7-12$ as many as $26.92 \%(1,084 \mathrm{MI})$, and have more than 12 learning group as much as $4.22 \%$ (170) MI. The average number of student per class with under 15 students namely 29\% (1.187 MI), between 16-25 students were $48 \%$ (1920 MI), and more than 25 students were $23 \%$ (919 MI).

Based on national statistics, the average number of students in each MI learning group in Central Java was 21, equal to the average number of students per learning group nationwide. Some provinces even have the number of students per learning group only 15 students just as like in Yogyakarta, South Sulawesi, and West Sulawesi [15].

Based on the number of students per school and per group learning, there were still many small schools which operate inefficiently. There were $1,428 \mathrm{MI}$ that the number of students bellow 100. If seen the number of students per learning group there were 1,187 MI which includes a small learning group.

Based on Government Regulation No. 74 in 2008 a teacher has face-to-face teaching obligations between 24-40 hours. Under that regulation obout $89 \%$ of MI teachers have taught in accordance with the regulations, only $11 \%$ of teachers who did not meet the requirement. Most teachers fulfill the obligation of teaching hours through their own institutions (97\%), only few teachers which fulfill teaching obligations through other educational institutions (3\% of total teachers). A total of 584 teachers must fulfill their teaching obligations in other institutions and it is dominated by the private MI teacher of 559 people $(96 \%)$ of total teachers seek additional teaching elsewhere.

Judging from the number of students per learning group on MTs, the number of students less than 25 as many as $508 \mathrm{MI}$ (30\%), between 26-40 students as much as 1,121 (67\%), and there were few schools with students more than 40 per learning group. Those of small MTs majority was private (98\%) this indicates inefficient delivery of education. Meanwhile MTs by which have large number of students in urban areas.

Based on national statistics, the average number of students in each learning group on MTs in Central Java was 32 , higher than the average number of students per learning goup nationally was 29 . There was even a province that only has an average number of students of 22 as in Gorontalo.

Judging from teacher teaching loads in MTs many that have not met the teaching obligation rules. It can be seen from the number of hours they teach that less than 24 hours per week as many as 14379 teachers (42\%), which meets the Government Regulation No. 742008 between 24-40 hours per week as many as 18677 teacher (55\%), and who teach more than 40 hours per week as many as 1,025 teacher or $3 \%$.

So that teachers can meet the teaching obligations between 24-40 hours per week, then the MTs teachers not only taught in his/her own madrasah. They are looking for another madrasah or even other schools such as SD, SMP, SMA and SMK. There were 6,131 teachers who teach in more than one madrasah/school or by $18 \%$ of them.

The number of students who repeat also demonstrated efficiency levels of education. If in the year 2014/2016 there were 6,348 students nationwide who repeat in MI and 53,057 students who repeat MTs it will be calculated level of inefficiency within one year. Using assumption of BOS for MI Rp. 800,000 per student per year and BOS MTs Rp. 1,000,000 per student per year, it is more than Rp. 5 billion annually inefficiency in MI. While inefficiency in MTs more than Rp. 53 billion annually.

The number of students who drop out will also show the efficiency level of education. If it is assumed the average of drop out in the third year, means tha the efficiency for MI who drop out in 2014/2015 for 5,803 student equivalent to Rp. 14 billion and MTs who drop out for 14,564 students equivalent to Rp. 44 billion.

Student graduation rates also show the efficiency of the provision of education, because of the higher number of students who do not pass means increasing in inefficiency. If students do not pass form MI then repeat and eventually pass it just be inefficiency of one year only. However, if students do not graduate and not repeated and eventually drop out then the inefficiency for six years. Finally, the students do not get the economic benefits for six years following the educational process in MI. 
Since the BOS program, many madrasah have no financial problems. What they required know is manage madrasah efficienly. Based on the research results, BOS at the madrasah very helpful and have a great impact on the management of the institution [8]. Though madrasah no longer facing financial problems, but there are still many madrasah have bad quality and should receive strengthening in quality. So one suggestion is to improve the quality of madrasah by implementing quality improvement management based on a holistic madrasah management components.

\section{The Professionalism of Madrasah Teachers}

Teacher professionalism can be seen from the fulfillment of the minimum academic qualification of S1 or D4, teaching certificate, and the fit between the educational background of its teaching certificate as a representation of teaching subjects. Those criteria stated explicitely and implicitely in the Act No. 20 of 2003 and Act No. 14 of 2005.

The number of active teachers in MI in 2016 as many as 43,008 people, consisting of 40.516 teachers and 2,492 administrators [23]. For teachers, as many as 6,117 (15\%) of them did not meet the academic qualifications, while as many as $34,399(85 \%)$ already qualified as teachers. Of the total number of MI teachers who did not meet the academic qualification as many as 4,579 (11\%) hold high school background. The data show that there has been a significant increase compared with the nationwide condition in the year 2000 , the number of teachers who did not meet minimum competency reached $47 \%$ [10]. These data also showed that the conditions of MI teachers in Central Java was better than the condition of madrasah teachers in general.

Judging from its professionalism as evidenced by the teacher certificate, as much as $54 \%$ of MI teachers were professionals meanwhile $46 \%$ of them have not been professional. Especially for teachers who already have a teaching certificate, as much as $85 \%$ of certification in accordance with the background of study program or clumps of field studies and only $15 \%$ were not in accordance with clumps of subjects. Judging from the ownership of certificate of MI teachers seem that the conditions in Central Java Province also better if compared in 2000 condition nationwide, that showed $63 \%$ of MI teacher did not meet the academic qualification and certification.

Number of active MTs teachers as many as 34,081 consisting of 5,637 them teaching at public MTs and 28,444 teaching at private MTs. According to the employment status as many as 6,573 (19\%) were civil servants and as many as $27,508(81 \%)$ were non civil servant. Based on the academic qualifications of teachers, a total of 4,598 (13\%) have not yet qualified as a teacher, even among those who have not qualified there are 3,541 hold high-school education background or equals. The already qualified as a teacher as much as 29,483 people $(87 \%)$ since they have S1 or D4 academic background.
Of the total active MTs teachers who already have a teaching certificate or on the process of obtaining a certificate were $51 \%$ (17,256 teachers). While the other not yet have a teaching certificate as much as $49 \%$ (16,285 teachers).

Of the total MTs teacher who already certified as many as 17,265 of them, who hold certification not correspond to the original educational background as many as 5,308 (31\%). This means that teacher whose certification allied with their fields of study or educational background of origin as many as 11,957 people $(69 \%)$.

With those conditions it is important to the MORA to plan continuous professional development for madrasah teacher. It's better if continuous professional development for teacher designed compehensively starting from the process of recruitment, placement, up to a teacher retirement. Because based on the results of the study [9], if teacher professional development were planned well based on the results of teacher evaluation will improve the quality of learning that can ultimately improve student achievement in academic and nonacademic.

In the perspective of Islam, a teacher needs to be balance between the material and mental needs. So to improve the quality, a Muslim teacher needs to change and evolve according to the progress of education. Despite the fact that to improve the quality of teachers through a complex process that includes hardware, software, and devices thought including the willingness of the government to increase the education budget [10].

The government has sought to improve professionalism of madrasah teachers through the certification. Unfortunately based on the results of research, teacher certification does not have posifit impact the performance of teachers in the learning process [11].

\section{The Quality of Madrasah Graduates}

The quality of madrasah graduates in this article viewed from the achievements of MI and MTs students academic year 2014/2015 which was reported by the MORA in 2016. The achievement MTs and SMP based on the subjects tested on the national examination in 2014, 2015 and 2016 based on reports of MOEC in 2016.

The graduates quality of MI in Central Java in 2014/2015 was lower than the national average, namely $6.73<7.09$. Similarly, graduates of MTs in Central Java in the same year was lower than the national average, namely $6.36<6.74$ [15]. This shows that the various resources used in Central Java, which include teachers and administrators, funding, and infrastructure did not provide maximum impact on student learning outcomes.

Based on the national test scores (as one of the benchmarks on quality of national education) during the last three years the average score of MTs in Central Java was always lower than the average score of SMP students. Based on the everage score of top 50 SMP in 2015/2016 academic year had an average of 
79.60 while average score of MTs was 61.58 MTs. It means the average score of MTs students was lower 18.03 than the average schore of SMP students. Based on the top 50 participants in national exam of SMP in 2014/2015 academic year had an average of 78.34 and MTs have average score 61.74. Its means that the average score of MTs students was 16.60 lower than the average score of SMP students.

The difference in the average score of national exam on MTs will be much lower when seen from the overall score of students who took the exam. In the 2014/2015 academic year the average score of national exam on SMP students within 35 districts/cities in Central Java was 76.53. Meanwhile in the same year the average score of the national exam of MTs students throughout Central Java was 53,37. This means that the average score of MTs in Central Java was 23.16 lower than the average score of SMP students.

Society wants the Islamic education became one of the alternative of education. It would require a new paradigm for improving the quality of Islamic education. The new paradigm ranging from the formulation of the vision, mission, goals, curriculum, strategies, methods, funding, government support, and management and leadership in Islamic education [12].

Madrasah has a dual strategic role as an educational institution and social institutions. As an educational institution madrasah has a typical religious, its Islam. As a social institution, the presence of madrasah awaited by the community as agents of change and development of society [13].

Since the importance role of madrasah as agents of change in society, it becomes very important to improve the quality of madrasah graduates. In fact the quality of madrasah graduates was less than the general school graduates. Besides the lack of quality, views of society on madrasah are still tilted, caused the number of madrasah student was much less than school students. It can be seen from the gross enrollment rate (GRE) of education. The contribution of MI on national GRE only $13 \%$ and the contribution of MTs on national GRE was $24 \%$. The condition in Central Java was better since GRE for MI reached $13 \%$ and GRE for MTs reached 26\% [15]

\section{CONCLUSION}

Based on the results of the general discussion above concluded that madrasah have good quality although still much to be improved both in terms of institutional, efficiency, professionalism of teachers, and the quality of graduates. Especially the quality of MTs graduates is lower when compared to the quality of SMP. In order to be better quality of madrasah and to achieve effective madrasah, it is advisable to do institutional reforms concerning the management of madrasah related to institutional management, teacher management, financial management of madrasah.

Central Government, Local Government, and the MORA should make a policy for implementation of the more efficient and effective madrasah by setting the ideal number of students and teachers' teaching load reasonable. One of the policies to regulate the ideal number of students is to limit the establishment of the adjacent madrasah. Governments also need to create new rules that teachers' teaching load is calculated not only from face-face lessons, but starting from the preparation of teaching to the evaluation.

To improve the professionalism of madrasah teachers, the Government and MORA need to accelerate the program of S1/D4 to continue to provide assistance to teachers who are still potential for continuing education. One of the obstacles to gain academic qualifications S1/D4 is the lack of higher education providers in the local area. Therefore, the MORA at provincial and district level need to work with Institute of Teacher Training to provide educational services, especially to remote areas.

The quality of madrasah graduates would be better if supporting components of madrasah education continued to improvement. With the better infrastructure, more professional teachers, the use of the budget more efficient and effective, as well as better institutional management of madrasah will facilitate the achievement of effective madrasah.

MORA has conducted limited competence test on madrasahah teacher, in contrast with the MOEC which since 2012 has been tested the competence of teachers more broadly. It is recommended that the MORA immediately conducting competence test to madrasah teacher thoroughly to know the strengths and weaknesses of them. Based on these weaknesses then conduct an ongoing professional development program to madrasah teachers.

\section{ACKNOWLEDGMENT}

Further thanks to the Central MORA and the MORA in Central Java Province which has provided the necessary data in the writing this article.

\section{REFERENCES}

[1] Umar. Madrasah Transformatif, Best Practices Pengelolaan Madrasah di Kota Santri. Semarang: Fatawa Publishing, 2015, pp. 2-3.

[2] Zuhdi, M. Modernization of Indonesian Islamic schools' curricula, 1945-2003. International Journal of Inclusive Education, 10, 2016, pp. 416-417.

[3] Undang-Undang Nomor 4 tahun 1950 tentang Dasar-Dasar Pendidikan dan Pengadjaran Di Sekolah, Bab V, Pasal 10, ayat 2.

[4] Umar. Revolusi Madrasah, Mozaik Perjuangan Tiga Kota. Jakarta: Jawara Media, 2015, p. 5.

[5] Undang-Undang Nomor 2 tahun 1989 tentang "Sistem Pendidikan Nasional", Bab IV, Pasal 10 dan 11.

[6] Undang-Undang Nomor 20 tahun 2003 tentang "Sistem Pendidikan Nasional", Bab VI, pasal 17.

[7] Umar. Revolusi Madrasah, Mozaik Perjuangan Tiga Kota. Jakarta: Jawara Media, 2015, pp. 5-6.

[8] Makruf, R. B. Manajemen Peningkatan Mutu Madrasah Swasta. ElHikmah, 10, Juni 2016, p. 65.

[9] Yasin, A. F. Pengembangan Kompetensi Pedagogik Guru Pendidikan Agama Islam Di Madrasah (Studi Kasus Di MIN Malang I). ElQUDWAH, 2012, p. 157 
[10] Natsir, N. F. Peningkatan Kualitas Guru dalam Perspektif Pendidikan Islam. Educationist, 1, 2007, p. 20.

[11] Hurmaini, M. Dampak pelaksanaan sertifikasi guru terhadap peningkatan kinerja guru dalam proses pembelajaran: Studi pada Madrasah Tsanawiyah Negeri Kota Jambi. Media Akademika, 26, 2011, p. 525 .

[12] Sanaky, H. A. Permasalahan dan Penataan Pendidikan Islam Menuju Pendidikan yang Bermutu. EL TARBAWI, 1, 2008, p. 83

[13] Haningsih, S. Peran strategis pesantren, madrasah dan sekolah islam di Indonesia. EL TARBAWI, 1, 2008, p. 27

[14] Majalah Pendidikan Islam Kementerian Agama. Pendis, edisi No. 7 tahun IV, 2016, pp.13.

[15] Direktorat Pendidikan Islam Kementerian Agama. "Statistik Pendidikan Islam Tahun Pelajaran 2014/2015, 2016”, pp. 9-49.

[16] Parker, L. \& R. Raihani. Democratizing Indonesia through education? Community participation in Islamic schooling. Educational Management Administration \& Leadership, 39, 2011. p. 712

[17] Wright, J. D. \& D. G. Hodgson. International Encyclopedia of the Social \& Behavioral Sciences, vol. 6, 2015, p. 80.

[18] Reynolds, D. "School Effectiveness in Developed Societies", 2010, p. 269.

[19] Tan, C. Islamic education and indoctrination: The case in Indonesia. Routledge, 2012, p. 91.

[20] Hefner, R. W. Making modern Muslims: the politics of Islamic education in Southeast Asia. University of Hawaii Press, 2009, pp. 9697.

[21] Carnoy, M. \& H. M. Levin. The Limits of Educatonal Reform. 1-290. New York: David McKay Company, Inc, 1976, p. 31.

[22] Peraturan Pemerintah Republik Indonesia

[23] Kementerian Agama Provinsi Jawa Tengah. "Data Lembaga RA, MI, MTs, dan MA, 2016". 